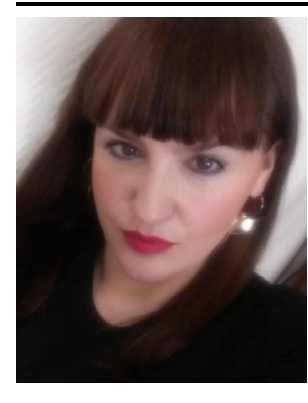

УДК [631.158:658.310.16]:332.1

https://doi.org/10.47612/978-985-7149-55-1-2020-134-136

Виктория Лёвкина, кандидат экономических наук, ведущий научный сотрудник

Институт системных исследований в АПК НАН Беларуси, г. Минск

\title{
Организационно-экономические фракторы роста производительности аграрного труда \\ в региональной экономике
}

Исследования показывают, что социально-экономическое развитие регионов Беларуси носит дифференцированный характер. Это обусловлено различными факторами, среди которых природно-климатические, демографические, экономические, культурно-исторические [1-6]. Детальное изучение условий и особенностей развития регионов позволяет обосновать основные направления повышения эффективности экономической деятельности хозяйствующих субъектов, скорректировать с учетом этого социальный вектор развития сельской местности.

Объектом исследования в данной статье являются сельскохозяйственные организации Витебской и Могилевской областей, предметом исследования - процесс производства сельскохозяйственной продукции работником и создание им добавленной стоимости.

Оценка трудового потенциала показывает, что в 2019 г. по виду экономической деятельности «Растениеводство и животноводство, охота и предоставление услуг в этих областях» в сельских населенных пунктах Витебской и Могилевской областей было занято $24,8 \%$ от аналогичного показателя всех занятых в республике. Среднегодовая численность работников в одной сельскохозяйственной организации - 148 чел. Показатель эффективности труда - производство валовой продукции на 1 чел.-ч - имел значение на уровне 17,3 руб. Среднемесячная заработная плата работников в сельхозорганизациях Витебской и Могилевской областей составила 632 руб.

Детализированный анализ показателей производительности труда свидетельствует, что производство валовой продукции в расчете на одного работника либо 1 чел.-ч в Витебской и Могилевской областях ниже, чем среднереспубликанское значение (табл. 1). Трудоемкость производства основных видов сельскохозяйственной продукции, соответственно, превышает аналогичный показатель по республике. При этом можно сделать вывод, что для исследуемого региона актуальна проблема повышения эффективности производства животноводческой продукции: в Витебской области затраты труда на производстве прироста КРС в 1,5 раза выше, чем среднее значение по республике, в Могилевской области в свиноводстве - в 2,2 раза.

В результате исследований, выполненных ранее сектором рынка труда Институга системных исследований в АПК НАН Беларуси, выявлено, что основной причиной использования в животноводстве большого объема ручного труда является низкий уровень технико-технологической оснащенности предприятий $[4,5]$. В условиях высокой текучести кадров это приводит к разбалансированности организации труда работников животноводства: увеличению средней продолжительности рабочего дня, а также годового фонда рабочего времени,

Таблица 1. Показатели производительности труда в сельскохозяйственных организациях

\begin{tabular}{|c|c|c|c|c|c|c|c|c|}
\hline \multirow[b]{2}{*}{ Год } & \multirow{2}{*}{$\begin{array}{l}\text { Произведено валовой про- } \\
\text { дукции на одного среднего- } \\
\text { дового работника, тыс. руб. }\end{array}$} & \multirow{2}{*}{$\begin{array}{l}\text { Произведено вало- } \\
\text { вой продукции } \\
\text { на } 1 \text { чел.-ч, руб. }\end{array}$} & \multicolumn{6}{|c|}{ Затраты труда на производство 1 ц продукции, чел.-ч } \\
\hline & & & зерно & $\begin{array}{c}\text { сахарная } \\
\text { свекла }\end{array}$ & картофель & молоко & \begin{tabular}{|c|} 
прирост \\
КРС
\end{tabular} & $\begin{array}{l}\text { привес } \\
\text { свиней }\end{array}$ \\
\hline \multicolumn{9}{|c|}{ 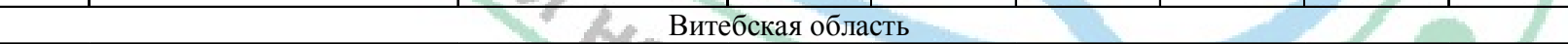 } \\
\hline 2005 & 11489 & 5379 & 1,6 & 0,7 & 3,2 & 5,8 & 35,7 & 14,3 \\
\hline 2010 & 41218 & 18512 & $-1,2$ & - & 2,3 & 4,2 & 24,5 & 9,5 \\
\hline 2015 & 246472 & 115332 & 0,6 & - & 1,2 & 3,7 & 23,6 & 6,6 \\
\hline 2018 & 34,7 & 15,9 & 0,8 & 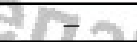 & 1,2 & 3,2 & 22,4 & 6,8 \\
\hline 2019 & 38,6 & 18,0 & 0,7 & -9 & 1,0 & 3,1 & 22,7 & 6,8 \\
\hline \multicolumn{9}{|c|}{ Могилевская область } \\
\hline 2005 & 14040 & 6093 & \begin{tabular}{|l|}
1,3 \\
\end{tabular} & 0,3 & 1,5 & 5,1 & 32,7 & 27,2 \\
\hline 2010 & 49964 & 21690 & 0,9 & 0,3 & 1,1 & 3,2 & 19,4 & 10,6 \\
\hline 2015 & 273051 & 125786 & 0,8 & 0,3 & 0,8 & 2,8 & 18,0 & 8,5 \\
\hline 2018 & 36,4 & 17,5 & 0,9 & 0,1 & 0,5 & 2,7 & 18,0 & 16,2 \\
\hline 2019 & 40,5 & 19,0 & 0,8 & 0,09 & 0,5 & 2,8 & 9,8 & 11,8 \\
\hline \multicolumn{9}{|c|}{ Республика Беларусь } \\
\hline 2005 & 15958 & 7269 & 1,0 & 0,4 & 2,3 & 4,8 & 29,1 & 13,9 \\
\hline 2010 & 48544 & 21637 & 0,8 & 0,2 & 1,5 & 3,2 & 19,8 & 9,9 \\
\hline 2015 & 307159 & 141240 & 0,5 & 0,1 & 1,0 & 2,5 & 16,4 & 6,3 \\
\hline 2018 & 44,9 & 20,6 & 0,7 & 0,09 & 0,9 & 2,1 & 15,1 & 6,0 \\
\hline 2019 & 51,7 & 24,0 & 0,6 & 0,07 & 0,9 & 2,0 & 14,7 & 5,3 \\
\hline
\end{tabular}

Примечание. Таблица составлена по данным сводных годовых отчетов сельскохозяйственных организаций системы Минсельхозпрода. 
снижению ответственности при выполнении должностных обязанностей, несоблюдению трудовой и производственной дисциплины, нарушению регламентов производства сельскохозяйственной продукции.

Как видно из анализа годового фонда рабочего времени работников животноводства, в Витебской области количество отработанных дней одним работником приближено к среднереспубликанскому уровню, в Могилевской - значительно выше (табл. 2). Данные таблицы 2 свидетельствуют, что средняя продолжительность рабочего дня в животноводстве в Витебской области увеличивается. В качестве положительной тенденции можно отметить сокращение средней продолжительности рабочего дня в животноводстве региона в долгосрочном периоде. Ретроспективный анализ показал, что в Витебской области данный показатель в 2012 г. составлял 11,3 ч, в 2016 г. - 11,3; в Могилевской области - 10,4 и 9,8 ч соответственно.

Данную тенденцию можно объяснить в первую очередь повышением инвестиционного показателя аграрного производства, модернизацией рабочих мест в сельскохозяйственных организациях. Так, согласно проведенным расчетам, на одного среднегодового работника сельскохозяйственной организации приходилось инвестиций (тыс. руб/чел.):

-в Витебской области: 2016 г. -8,12; 2017 г. - 11,73; 2018 г. $-27,21 ; 2019$ г. $-22,84$;

- в Могилевской области: 2016 г. - 7,57; 2017 г. - 6,85; 2018 г. $-9,38 ; 2019$ г. $-12,6$;
- по Республике Беларусь: 2016 г. - 8,82; 2017 г. 10,48; 2018 г. - 13,44; 2019 г. $-15,58$.

Повышение инвестиционной привлекательности сельского хозяйства является необходимым условием роста производительности труда аграрных работников и, как следствие, их заработной платы. Анализ динамики начисленной среднемесячной заработной платы в отрасли и ее уровня по отношению к среднереспубликанскому значению показал рост данных показателей за 2017-2019 гг., особенно в Витебской области (табл. 3).

Исследования свидетельствуют, что рост заработной платы работников аграрной отрасли Витебской области экономически обоснован. Это подтверждает показатель валового дохода в расчете на одного работника, который также характеризует производительность труда (табл. 4). Валовой доход является важнейшей экономической категорией, источником расширенного воспроизводства и роста заработной платы.

Так, в сельском хозяйстве Витебской области за 20172019 гг. валовой доход в расчете на одного работника увеличился в 2,3 раза. Тем не менее расчеты свидетельствуют, что созданного валового дохода для расширенного производства недостаточно. На это указывает доля фонда оплаты труда работников в валовом доходе, которая превышает $100 \%$. Проведенные ранее исследования показали, что в экономически сильных сельскохозяйственных организациях данный показатель варьирует в диапазоне 40-60\%.

Таблица 2. Показатели рабочего времени в животноводстве, 2017-2019 гг.

\begin{tabular}{|c|c|c|c|c|c|c|c|c|c|}
\hline \multirow{2}{*}{8 Показатели } & \multicolumn{3}{|c|}{ Витебская область } & \multicolumn{3}{|c|}{ Могилевская область } & \multicolumn{3}{|c|}{ Республика Беларусь } \\
\hline & 2017 г. & 2018 г. & 2019 г. & 2017 г. & 2018 г. & 2019 г. & 2017 г. & 2018 г. & 2019 г. \\
\hline $\begin{array}{l}\text { Количество отработанных дней } \\
\text { одним работником животноводства, } \\
\text { дней }\end{array}$ & 284 & 286 & 283 & 300 & 292 & 295 & 286 & 286 & 287 \\
\hline $\begin{array}{l}\text { Средняя продолжительность рабо- } \\
\text { чего дня в животноводстве, ч }\end{array}$ & 8,9 & 9,0 & 9,2 & 9,5 & & 9,4 & 9,2 & 9,2 & 9,2 \\
\hline
\end{tabular}

Примечание. Таблица составлена по данным сводных годовых отчетов сельскохозяйственных организаций системы Минсельхозпрода.

Таблица 3. Показатели начисленной среднемесячной заработной платы в сельском хозяйстве и экономике, 2017-2019 гг.

\begin{tabular}{|c|c|c|c|}
\hline затели & 2017 г. & 2018 г. & 2019 г. \\
\hline - Витебская область & & 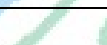 & +2 \\
\hline \multicolumn{4}{|l|}{ Номинальная начисленная среднемесячная заработная плата работников, руб.: } \\
\hline по экономике в целом & 687,3 & 814,4 & 911,8 \\
\hline в сельском хозяйстве & 484,0 & 580,0 & 684,3 \\
\hline $\begin{array}{l}\text { Отношение номинальной начисленной среднемесячной заработной платы } \\
\text { работников в сельском хозяйстве к среднереспубликанскому уровню, \% }\end{array}$ & 70,4 & 71,2 & 75,0 \\
\hline \multicolumn{4}{|l|}{ Могилевская область } \\
\hline $\begin{array}{l}\text { Номинальная начисленная среднемесячная заработная плата работников, руб.: } \\
\text { по экономике в целом }\end{array}$ & 690,4 & 802,0 & 891,6 \\
\hline в сельском хозяйстве & 518,7 & 585,4 & 671,2 \\
\hline $\begin{array}{l}\text { Отношение номинальной начисленной среднемесячной заработной платы } \\
\text { работников в сельском хозяйстве к среднереспубликанскому уровню, \% }\end{array}$ & 75,1 & 73,0 & 75,3 \\
\hline \multicolumn{4}{|l|}{ Республика Беларусь } \\
\hline $\begin{array}{l}\text { Номинальная начисленная среднемесячная заработная плата работников, руб.: } \\
\text { по экономике в целом }\end{array}$ & 822,8 & 971,4 & 1092,9 \\
\hline в сельском хозяйстве & 564,0 & 651,5 & 787,1 \\
\hline $\begin{array}{l}\text { Отношение номинальной начисленной среднемесячной заработной платы } \\
\text { работников в сельском хозяйстве к среднереспубликанскому уровню, \% }\end{array}$ & 68,5 & 67,1 & 69,1 \\
\hline
\end{tabular}

Примечание. Таблица составлена по данным Национального статистического комитета Республики Беларусь. 
Таблица 4. Взаимосвязь валового дохода, созданного в сельском хозяйстве, и мотивации труда аграрных работников, 2017-2019 гг.

\begin{tabular}{|c|c|c|c|}
\hline Показатели & 2017 г. & 2018 г. & 2019 г. \\
\hline \multicolumn{4}{|l|}{ Витебская область } \\
\hline Валовой доход, тыс. руб. & 73722,9 & 143522 & 182419 \\
\hline $\begin{array}{l}\text { Произведено валового дохода на одного среднегодового работника, } \\
\text { тыс. руб/чел. }\end{array}$ & 2,87 & 5,28 & 6,69 \\
\hline Фонд оплаты труда, тыс. руб. & 176623,2 & 216954 & 252412 \\
\hline Доля фонда оплаты труда в валовом доходе, \% & 239 & 151 & 138 \\
\hline \multicolumn{4}{|l|}{ Могилевская область } \\
\hline Валовой доход, тыс. руб. & 138379,2 & 182029 & 168857 \\
\hline $\begin{array}{l}\text { Произведено валового дохода на одного среднегодового работника, } \\
\text { тыс. руб/чел. }\end{array}$ & 7,15 & 8,14 & 8,25 \\
\hline Фонд оплаты труда, тыс. руб. & 131555 & 161420 & 171195 \\
\hline Доля фонда оплаты труда в валовом доходе, \% & 95 & 89 & 101 \\
\hline 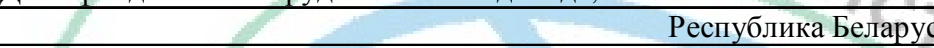 & -2 & & \\
\hline Валовой доход, тыс. руб. & 885291 & 1207936,9 & 1222046,5 \\
\hline $\begin{array}{l}\text { Произведено валового дохода на одного среднегодового работника, } \\
\text { тыс. руб/чел. }\end{array}$ & & 6,42 & 6,75 \\
\hline Фонд оплаты труда, тыс. руб. & 1552642,3 & 1742876,6 & 1943965,1 \\
\hline Доля фонда оплаты труда в валовом доходе, \% & 175 & 144 & 159 \\
\hline
\end{tabular}

Примечание. Таблица составлена по данным сводных годовых отчетов сельскохозяйственных организаций системы Минсельхозпрода.

Таким образом, установлено, что рост производительности труда в сельскохозяйственных организациях обусловлен в первую очередь долгосрочными капитальными вложениями в сельскохозяйственное производство. Это способствует оптимизации режима рабочего времени работников животноводства в долгосрочном периоде, росту заработной платы. Тем не менее вопрос повышения производительности труда в животноводстве остается нерешенным, требуется дальнейшее совершенствование организации труда работников - peжима труда и отдыха, производственной и технологической дисциплины и др.

\section{Список использованных источников}

1. Лёвкина, В. О. Демографический аспект воспроизводства трудовых ресурсов села Беларуси / В. О. Лёвкина // Аграр. экономика. - 2016. - № 4. - С. 14-22.

2. Лёвкина, В. О. К вопросу об уровне профессиональной подготовки кадров массовых профессий сельскохозяйственных организаций Могилевской области / В. О. Лёвкина // Актуальные проблемы формирования кадрового потенциала для инновационного развития АПК : материалы 3-й Междунар. науч.-практ. конф. Минск, 9-10 июня 2016 г. / БГАТУ ; редкол.: Н. Н. Романюк [и др.]. - Минск, 2016. - С. 153-155.
3. Пашкевич, О. А. Зарубежный опыт развития сельских территорий / О. А. Пашкевич, В. О. Лёвкина // Вестн. БГСХА. - 2017. - № 4. - С. 9-15.

4. Пашкевич, О. А. Мотивация труда работников животноводства: новые подходы / О. А. Пашкевич, В. О. Лёвкина // Вестн. БГСХА. - 2018. - № 2. - С. 29-34.

5. Пашкевич, О. А. Проблемы и направления совершенствования порядка оплаты труда в сельскохозяйственных организациях / О. А. Пашкевич, В. О. Лёвкина // Экономические вопросы развития сельского хозяйства Беларуси : межвед. темат. сб. / Ин-т систем. исслед. в АПК НАН Беларуси ; редкол.: В. Г. Гусаков (гл. ред.) [и др.]. - Минск, 2019. - Вып. 47. - С. 236-246.

6. Прогноз развития рынка труда в агрогородках с учетом комплексной модернизации сельского хозяйства / М. Н. Антоненко [и др.] // Научные принципы регулирования и развития АПК: предложения и механизмы реализации / В. Г. Гусаков [и др.] ; редкол.: В. Г. Гусаков (гл. ред.) [и др.]. - Минск : Ин-т систем. исслед. в АПК НАН Беларуси, 2016. - Гл. 5, § 5.1. С. 141-151.

7. Статистический ежегодник Республики Беларусь 2019 / Нац. стат. ком. Респ. Беларусь. - Минск, 2019. $472 \mathrm{c}$. Материал поступил 08.10.2020 2. 